\title{
OCCURRENCE, ABUNDANCE, DISTRIBUTION AND IDENTIFICATION OF ZOOPLANCTON WITH EMPHASIS ON MARINE INVERTEBRATE LARVAE FROM ADMIRALTY BAY
}

http://dx.doi.org/10.4322/apa.2014.008

\author{
Theresinha Monteiro Absher ${ }^{1 *}$, Andrea Cancela da Cruz-Kaled ${ }^{2}$, Karin Lutke Elbers ${ }^{2}$ \\ ${ }^{1}$ Centro de Estudos do Mar, Universidade Federal do Paraná, Pontal do Sul, PR, Brazil \\ ${ }^{2}$ Curso de Pós-Graduação, Instituto Oceanográfico, USP, São Paulo, SP, Brazil
}

*e-mail: tmabsher@ufpr.br

Zooplankton is one of the components of plankton and consists of a diversified group of invertebrate that live in the water column of the oceans, seas, rivers and lakes. They have an important role in the cycling of nutrients in the oceans since they are consumers of primary producers (phytoplankton) and in turn are consumed by larger organisms. According with the time of permanence in the plankton the zooplankton can be divided in two major groups: Holoplankton - organisms that stay in the plankton during all their life cycle and Meroplankton - organisms that are planktonic only during a phase of their life cycle and are made up mainly of larval stages of benthic marine invertebrates that possess life cycles with pelagic-benthic coupling (pelagic larvae associated to benthic adult). Each group of benthic organisms has a defined type of larvae, making it thus possible to identify the occurrence of the group at a certain time of the year. The study of the planktonic components are essential in monitoring programs and thus help to understand the abundance and distribution of shallow water benthic species. Meroplankton are good indicators for establishment of the factors that contribute or disturb the resilience and persistence of those communities. Previous studies at Admiralty Bay analyzed the vertical distribution of summer zooplankton (Chojnacki \& Weglenska, 1984), zooplankton changes during the year (Menshenina \& Rakusa-Suszczewski, 1992), the occurrence of gastropod larvae (Absher et al., 2003) and the seasonal variation of pelagic invertebrate larvae (Freire et al., 2006). The main objective of this work is to assess the occurrence, distribution, abundance and summer variation of zooplankton of shallow areas of Admiralty Bay and its correlation with oceanographic parameters (water and air temperature, salinity, transparency, chlorophyll $a$ concentration, wind speed and direction and nutrients) and thus evaluate the effects of environmental impact from anthropogenic activities. Quantitative sampling using a plankton net with a flowmeter was conducted in the shallow zone of Martel, Mackellar, Ezcurra Inlets, and near Arctowski Polish Station, during the summer 2009/2010. A plankton net of $50 \mathrm{~cm}$ diameter and $150 \mu \mathrm{m}$ mesh size was towed obliquely for 5 minutes at $30 \mathrm{~m}$ depth. Two consecutive tows at 5 fixed sampling sites: 1-Ferraz; 2-Botany Point; 3-Machu Pichu; 4-Point Thomas; 5-Arctowski (Figure 1) were accomplished on the same day. One additional station 6-Geleira Lange was sampled once only. The sampling series were accomplished on different dates spaced over at least five days. All samples were preserved in formaldehyde $4 \%$ neutralized with sodium borate. One additional tow at each one of the 5 sampling sites was sorted immediately after collection and some selected group of organisms fixed in modified Karnovsky (1995) media for analysis using Scanning Electron Microscopy (SEM) (Figure 2). 


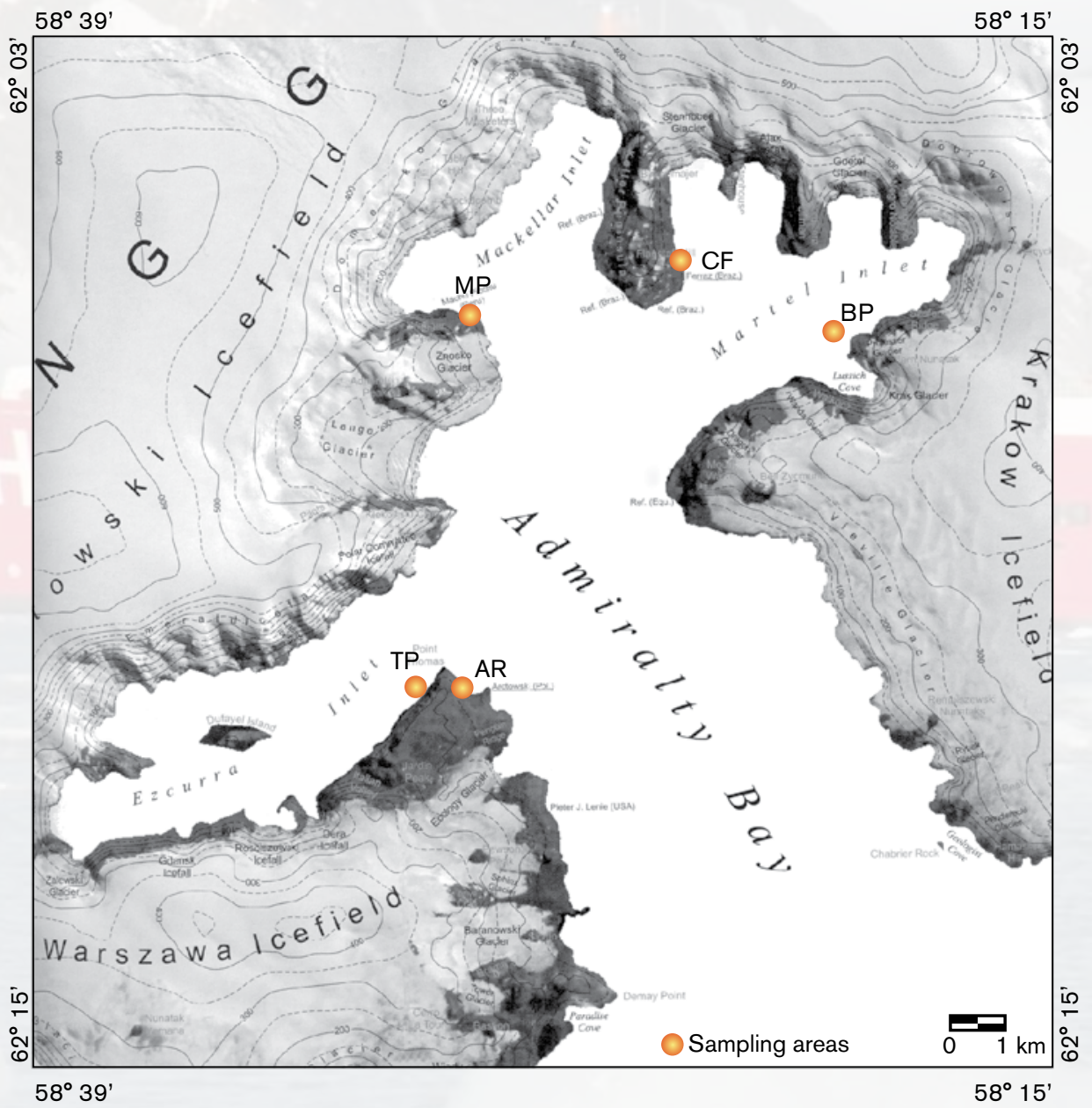

Figure 1. Sampling stations: CF-1 Ferraz; BP-2 Botany Point; MP- 3 Machu Pichu; TP - 4 Point Thomas; AR - 5 Arctowski; L - 6 Geleira Lange.
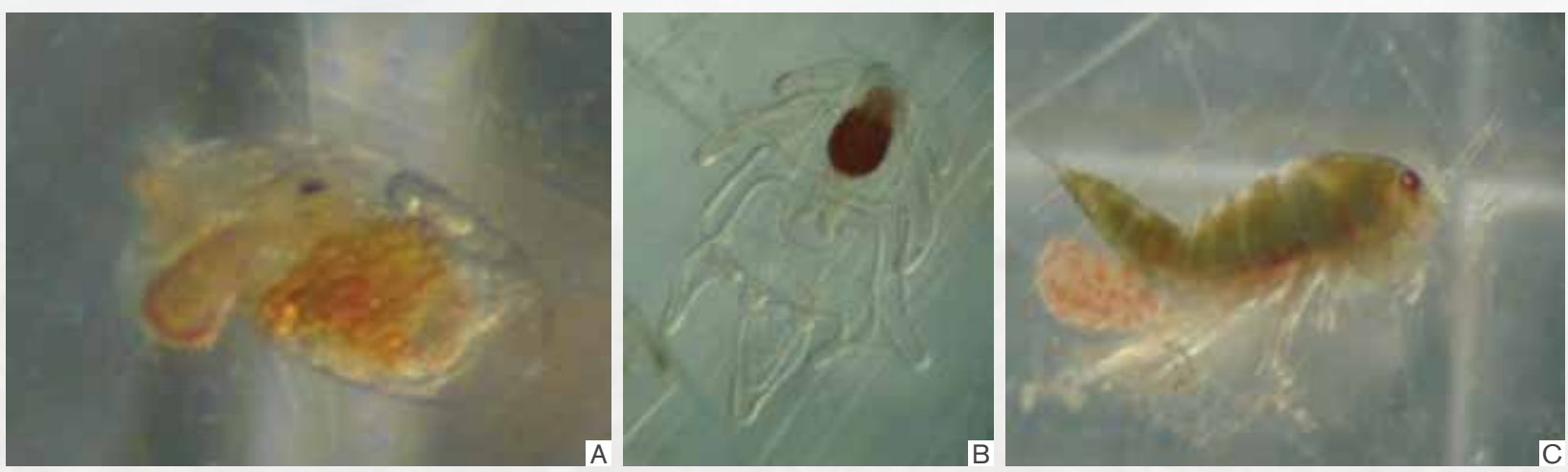

Figure 2. Some organisms for SEM analysis. a) Opisthobranchia larva; b) Bipinnaria larva; and c) Copepoda (Crustacea). 


\section{References}

ABSHER, T. M. et al. Pelagic larvae of benthic gastropods from shallow Antarctic Waters of Admiralty Bay, King George Island. Polar Biology, v. 26, p. 359-364, 2003.

CHOJNACKI, J.; WEGLENSKA, T. Periodicity of composition, abundance and vertical distribution of summer zooplankton (1977/1978) in Ezcurra Inlet, Admiralty Bay (King George Island, South Shetland). Journal of Plankton Research, v. 6, p. 807-827, 1984.

FREIRE, A. S. et al. Seasonal variation of pelagic invertebrate larvae in the shallow Antarctic waters of Admiralty Bay, (King George Island). Polar Biology, v. 29, p. 294-302, 2006.

MENSHENINA, L.; RAKUSA-SUSZCZEWSKI, S. Zooplankton change during the year in Admiralty Bay (February 1990-January 1991). Polskie Archiwum Hydrobiologii, v. 39, p. 65-76, 1992. 